\title{
Challenges For Tourism: A Changing Paradigm
}

María Cordente-Rodríguez, Ph.D., University CEU San Pablo, Spain

Juan-Antonio Mondéjar-Jiménez, Ph.D., University of Castilla-La Mancha, Spain

Águeda Esteban Talaya, Ph.D., University of Castilla-La Mancha, Spain

\begin{abstract}
The present environment is characterized for the uncertainty and crisis, and the existence of threats and dangers in the society and in the tourist sector for the survival of companies in the market. In addition, apart from changes in the economic situation, changes in demand occur in terms of new wants and needs, obliging suppliers to adapt to them in order to survive in times of a highly competitive environment and a difficult economic situation, when the key is not just attracting visitors, but also satisfying them in order to gain their loyalty. So the real threat is the lack of response to changing situations. The Spanish tourist sector is pressured by various threats such as the need to improve the competitiveness of destinations and products, make the industry more professional, encourage new forms of marketing and promotion, or change the sales model. Therefore, businesses must adapt to these changes and respond to them, strengthen the confidence of customers, who seek to obtain the optimum value for money. The objective of this paper is to evaluate the tourism activity in the town of Cuenca in the period 2005 to 2009, focusing the analysis on how supply changed to adapt to the requirements of demand. The aim being to evaluate their and correct errors, and design the actions of the future. That is to say, create an appropriate market strategy to promote the tourism product and ensure the idea of a consolidated tourist destination.
\end{abstract}

Keywords: Uncertainty; Competitiveness; Tourist Consumers; Tourist Destinations

\section{INTRODUCTION}

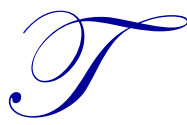

he current tourist market is characterized by the existence of heavy competition and by being in an intensive process of transformation, in which knowledge of the behavior of tourist demand and the modeling of this become a fundamental tool to reach a good position in relation to the competition and to adapt to the changes occurring in tourist markets (Gaztelumendi, 2009), the most important of which are these:

- $\quad$ Changes in tourist demand: in visitors' needs.

- $\quad$ Changes in destination management: the influence of image, development of facilities and services, etc.

- $\quad$ Changes in transport systems: the necessity of good accessibility.

- $\quad$ Changes in marketing strategies: increasingly segmented markets, greater competition and the need for differentiation are some of the changes observed.

So study of tourist consumers' behavior becomes a very important task for organizations and institutions, because only with knowledge of the consumer and his needs is it possible to be orientated towards them and satisfy them better than competitors (Devesa and Palacios, 2005); and it also allows tourism management to be improved, facilitating tourism managers' decision making, the choice of suitable promotional campaigns to be carried out, or decisions about new infrastructure investment (Molera and Albaladejo, 2007).

As a result of many actions carried out in recent years in the city of Cuenca, including Cuenca's Tourism Encouragement Plan, the city has consolidated itself as an inland tourist destination, offering a quality range of professionalized tourist services (Mondéjar, Mondéjar and Sevilla, 2009). 
However, changes in terms of both supply and demand in the field of tourism are highlighting new needs and at the same time requiring new strategies and plans of the managers involved in tourism activities (Gómez, Mondéjar and Sevilla, 2005).

Beginning from this premise, the purpose of this study is to analyze the characteristics of tourists and examine their development in the period 2005 to 2009, which have been identified by numerous authors, and use this study to verify their existence in the case of the Historic Fortified City of Cuenca, declared a World Heritage Site by UNESCO on December $7^{\text {th }}, 1996$.

\section{THE TOURIST CONSUMER}

The tourist consumer today has different characteristics to those he had in the past: these are the most important (Herrero, 2000):

- $\quad$ The consumer's behavior will be different at all times, depending on his motivation and the circumstances surrounding him. Nowadays, consumers seek to obtain the maximum value for money.

- $\quad$ Changing values: matters like quality, flexibility, awareness of environmental and cultural considerations and individualization are increasingly important. It could be said that we are changing from destruction of the landscape to ecological tourism, from over-crowding to absence of crowds, from beach tourism to contact with nature, or from hustle and bustle to the search for peace and quiet.

- Today's tourist consumer has more fragmented nights away from home, so that in the duration of his holidays, short stays, weekends and long weekends are predominant, and in the distribution of holidays over time, a trend towards spreading the month's holidays over the whole year is seen.

- Today's tourist has more information which, combined with prior experience of previous journeys, makes the consumer more demanding when it comes to making his purchase decision.

- Today's consumer is more active and independent. Tourists do not look for a standard, mass tourism package for their holidays, but like to feel different and so seek individualized tourism, concentrating their interest on peace and quiet, contact with nature, culture and avoiding crowds. In this way, they look for a balance between tourism, nature and culture and between the conservation and development of each region.

- Holiday planning is more spontaneous, reservations are made at the last minute, searching for offers (Esteban, 2005). Reservations in the past were made a long time in advance, this behavioral change is especially due to information and communication technologies which allow the distribution system to be altered by getting highly qualified information directly to the consumer.

things:

Mediano (2002) considers that the changes occurring in tourist consumers' behavior may be caused by three

1. Changes in the main motivation for the journey: new motivations appear and multiple motivations may even have an influence on the consumer; ecological motivations related with concern for the environment and respect for nature are beginning to appear forcefully.

2. Changes in the products and destinations demanded: the consumer is better informed and has experience and so is more qualified - knowing that the supply is broader, he demands products which match his needs exactly, i.e., he seeks a la carte products. The new categories of product include ecological tourism, longdistance tourism, thematic tourism (tourists visit places related with a specific theme, such as theme parks, museums, zoos, etc.) or active tourism, among others; these new products are a threat to traditional products but an opportunity for those who are able to understand the change.

3. Changes in tourism consumption: tourists use their holiday time in an enriching, beneficial way, for this purpose altering their consumption customs, shortening their stays or distributing them over the whole year.

Esteban (2005) considers that the crux of these changes is in the definition of leisure as an experience allowing the satisfaction of new tastes and desires, not in a single way, but taking advantage of the versatility of the activities carried out during the holiday, providing amusement, health, knowledge and the acquisition of goods, all in an environment or destination which offers attractions based on sustainability. So these are the main trends expected (Esteban, 2005): 
- $\quad$ More active, varied leisure time.

- $\quad$ Search for more opportunities.

- $\quad$ Fragmentation of holidays.

- $\quad$ More direct sales channels.

- Information-intensive activity.

- A la carte holidays.

- $\quad$ Quality combined with sustainability.

These new needs of tourists allow new products to be developed and possibilities arise for cultural tourism and tourism in rural areas.

The first studies of tourist consumers' behavior (Plog, 1974; Dann, 1977; Crompton, 1979; Mayo and Jarvis, 1981; Mazanec, 1983; Mill and Morrison, 1992) were based on motivations used to explain consumer behavior (Molina, 2002).

Many authors who have studied consumer behavior agree that this behavior is influenced by three types of factor (De Borja, Casanovas and Bosch, 2002):

- $\quad$ External or environmental factors: these are economic characteristics, demographic characteristics of the environment, cultural and social factors.

- Internal or personal factors: these are the basic structures of perception, where we find motivations, perception, learning, personality and attitudes.

- $\quad$ Marketing factors: among these factors, image creation, the creation of customer loyalty, public relations and the positioning of products and services stand out

Esteban (1996) indicates that these are the main variables allowing analysis of tourist consumers' behavior:

Tourism motives.

Reason for the choice of destination.

Type of accommodation used.

Means of transport used for the journey.

Ways of organizing the trip.

Characteristics of the holiday group.

$>\quad$ Duration of the holiday or stay.

$>\quad$ Distribution and concentration over time (seasonality).

$>\quad$ Expenditure made on the holiday and its distribution.

$>\quad$ Activities carried out during the visit.

$>\quad$ Satisfaction with the holiday overall and with its parts.

\section{METHODOLOGY}

\subsection{Sample description}

The data used for this study were obtained from surveys carried out on visitors to the city of Cuenca, who went to ask for information at tourist information offices in 2005, 2007 and 2009. This study was part of the city's Tourism Observatory project. The data sheet (Table 1) includes the most important details of the sample used for the study. 
Table 1: Technical record of the study

\begin{tabular}{|l|l|}
\hline Universe & Tourists aged above 18 \\
\hline Sample Unity & Individuals asking for information in tourist information offices \\
\hline Geographical Scope & Cuenca, a town declared a World Heritage site \\
\hline Methodology & Face-to-face survey using a structured questionnaire \\
\hline Sample Size & $2147(1075$ in 2005,968 in 2007 and 104 in 2009) valid surveys \\
\hline Sampliing Error & $\pm 5.49 \%$ \\
\hline Significance Level & $95 \%(\mathrm{p}=\mathrm{q}=0,5)$ \\
\hline Field Work Dates & 2005,2007 and 2009 \\
\hline
\end{tabular}

The assessment instrument used is a self-administered questionnaire with a Likert scale collecting information about different aspects of the journey made to Cuenca.

\subsection{Results}

\section{Previous experience of the destination}

From 2005 to 2009, an increase in the previous experience of the destination is observed, the frequency falling for the first visit and increasing for those who have been there more than four times (Graph 1); this tells us the improvement the city of Cuenca has undergone as a destination, managing to get its visitors to repeat. This is an indication of consolidation as a tourist destination and previous satisfaction with the destination, which will have a decisive influence on recommendation of the destination among relatives and friends, as well as the more positive image of the destination visitors generate.

\section{Graph 1: Previous experience of the tourist destination}

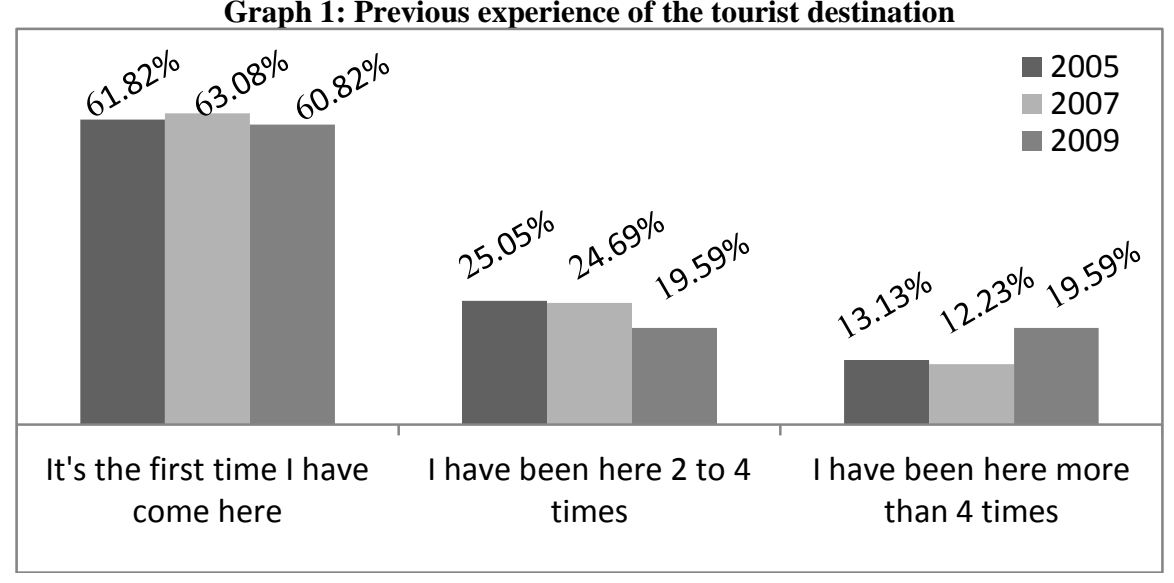

\section{Rating of the tourist destinations}

Visitors gave Cuenca an average rating of 7.8 points out of 10, which has remained stable for the last five years (Table 2); however, if we look at the compared opinion with other cities tourists have visited of similar characteristics, the score is lower, although continuous growth since 2005 is observed. This shows the increasing consolidation of the city of Cuenca as a heritage destination.

Table 2: Rating of Cuenca as a tourist destination

\begin{tabular}{|l|c|c|c|}
\cline { 2 - 4 } \multicolumn{1}{c|}{} & $\mathbf{2 0 0 5}$ & $\mathbf{2 0 0 7}$ & $\mathbf{2 0 0 9}$ \\
\hline General opinion & 7.84 & 7.80 & 7.88 \\
\hline Compared opinion & 6.90 & 7.02 & 7.12 \\
\hline
\end{tabular}




\section{$>\quad$ Medium or person who encouraged you to come}

The medium or person who encouraged the survey respondent to come to Cuenca has remained constant during this time. The main medium has been the recommendation of family and friends, followed by other media, Internet and communication media. Consultation of travel agencies and attendance at tourism fairs have fallen.

\section{$>\quad$ Reason for visit}

The main reason for the visit is cultural and/or leisure activity (Graph 2). However, in this period, a reduction in the proportion of tourists who give this reason is seen, in favor of visits to friends and/or relations and for professional reasons, i.e., new motivations appear and the decision to make the visit does not depend on a single motive but on a set of interrelated motivations (Valls, 1996).

Graph 2: Reason for the visit

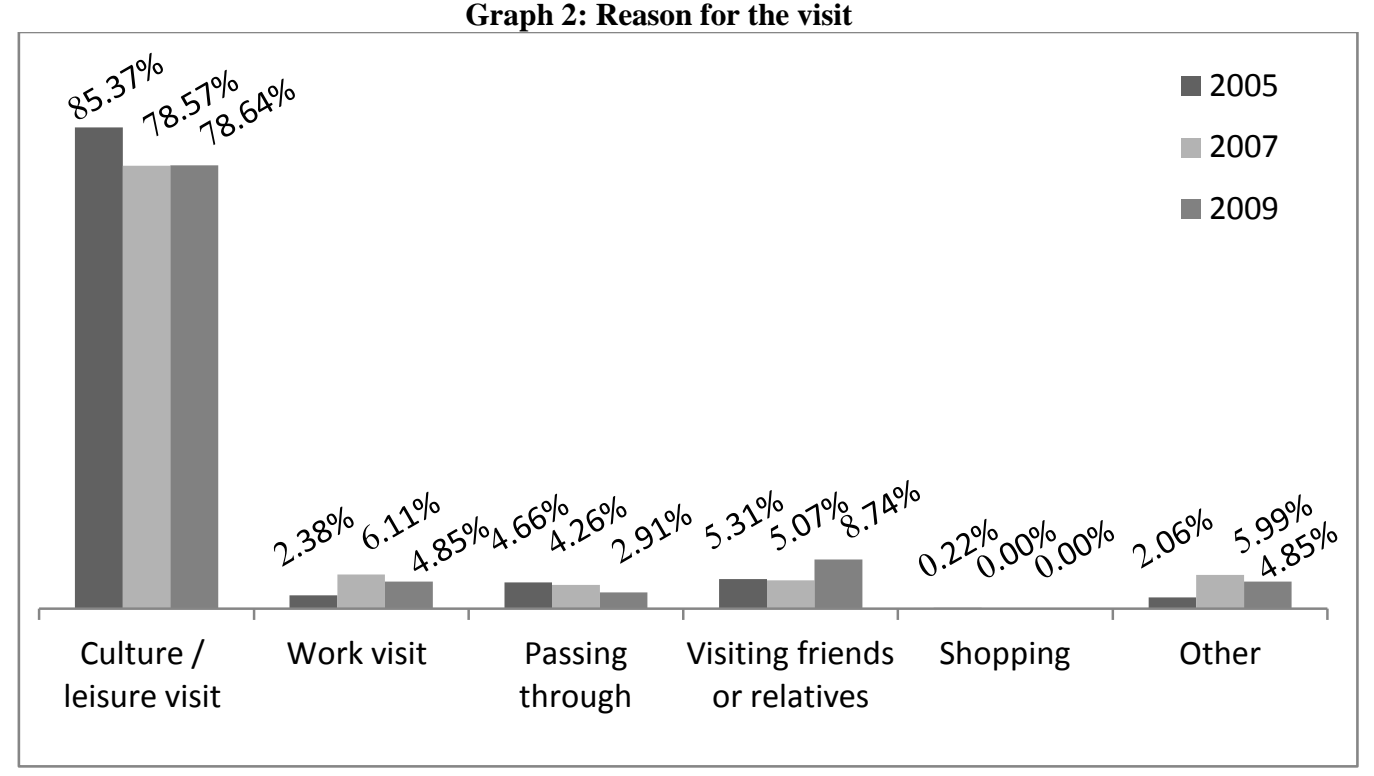

\section{Main activity carried out}

In 2005 and 2007, the main activity carried out by visitors to the city of Cuenca was visiting monuments and historic buildings, followed by enjoying nature, local gastronomy and visiting typical villages (Table 3 ). In 2009 , the main activities carried out were the same as the previous two years, except that the first place is shared by visiting monuments and enjoying nature, with the same proportion of preference. This tie shows the notable increase undergone by nature tourism.

The development shows an increase between 2005 and 2009 in the practice of sport and of night-time entertainment as the main activities carried out in the visit to Cuenca, to the detriment of visiting typical villages. The other activities remain the same.

These figures show the changes in the type of tourism preferred by visitors, with increased numbers of visits for other kinds of tourism than those traditionally carried out in Cuenca, such as cultural and nature tourism. 
Table 3: Main activity carried out

\begin{tabular}{|l|c|c|c|}
\cline { 2 - 4 } \multicolumn{1}{c|}{} & $\mathbf{2 0 0 5}$ & $\mathbf{2 0 0 7}$ & $\mathbf{2 0 0 9}$ \\
\hline Visit historic buildings & $83.44 \%$ & $66.53 \%$ & $72.12 \%$ \\
\hline Local gastronomy & $62.98 \%$ & $53.20 \%$ & $54.81 \%$ \\
\hline Visiting typical villages & $50.70 \%$ & $52.58 \%$ & $45.19 \%$ \\
\hline Studying Spanish & $4.74 \%$ & $7.02 \%$ & $6.73 \%$ \\
\hline Practicing sport & $13.12 \%$ & $14.15 \%$ & $18.27 \%$ \\
\hline Enojying nature & $77.95 \%$ & $59.81 \%$ & $72.12 \%$ \\
\hline Relaxation & $47.07 \%$ & $41.01 \%$ & $43.27 \%$ \\
\hline Night-time entertainment & $16.93 \%$ & $17.36 \%$ & $24.04 \%$ \\
\hline
\end{tabular}

\section{Length of stay}

The average stay in the city of Cuenca (Graph 3) fell slightly between 2005 and 2007, from 2.68 days to 2.51 days, but increased a lot in the last two years to 3.27 days in 2009. In the first period, from 2005 to 2007, the number of two-day stays increased, but all others fell, whereas in the period from 2007 to 2009 the number of longer stays, over three days, rose, while the others fell.

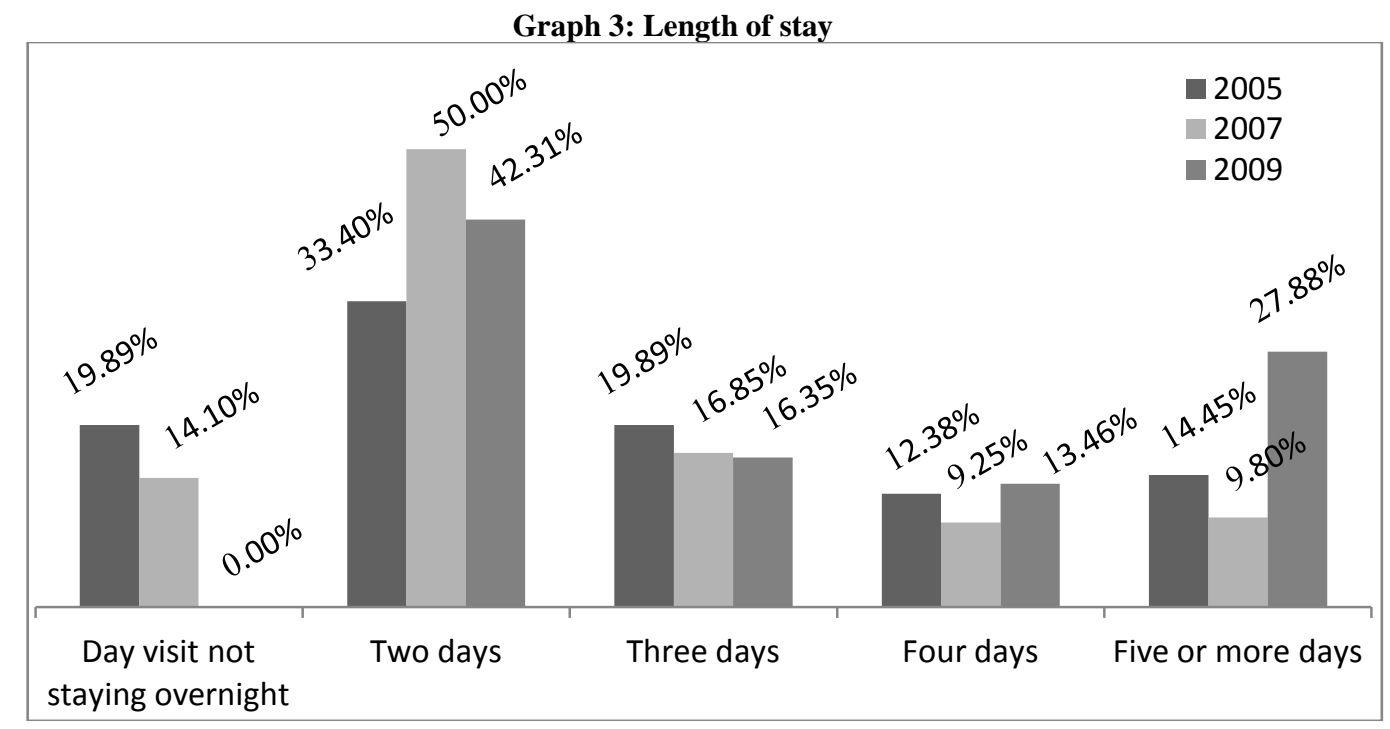

\section{$>\quad$ Daily expenditure}

One worrying figure is the overall reduction in the average daily expenditure per person in the period 20052009, in spite of the heavy increase undergone in 2007 (Table 4).

It is here that we see the effects of the economic crisis Spain is going through, which in the same way as it affects all sectors, is also damaging the tourist sector.

Table 4: Average daily expenditure (euros per person)

\begin{tabular}{|l|c|c|c|}
\multicolumn{1}{c|}{ Table 4: Average daily expenditure (euros per person) } \\
\cline { 2 - 4 } \multicolumn{1}{c|}{} & $\mathbf{2 0 0 5}$ & $\mathbf{2 0 0 7}$ & $\mathbf{2 0 0 9}$ \\
\hline Average daily expenditure & 64.41 & 74.35 & 63.55 \\
\hline
\end{tabular}

\section{Type of accommodation}

The development of the type of accommodation chosen by visitors (Graph 4) shows negative growth for one, three and four-star hotels. Increases are seen in lodging in two-star hotels, hostels/pensions, friends' homes, rural lodgings and camp sites/youth hostels. In other words, more expensive accommodation is being abandoned and cheap, alternative lodgings sought, corresponding to another kind of tourism, nature tourism or rural tourism. 
This behavior of a decline in the demand for traditional hotel establishments in favor of new methods has been seen clearly in the province of Cuenca in recent years (Mondéjar, Mondéjar, Sevilla and Cordente, 2009). And it is the result of changes in the tastes of consumers, who seek greater contact with nature and interaction with locals, but also a consequence of the economic situation of crisis our country is suffering.

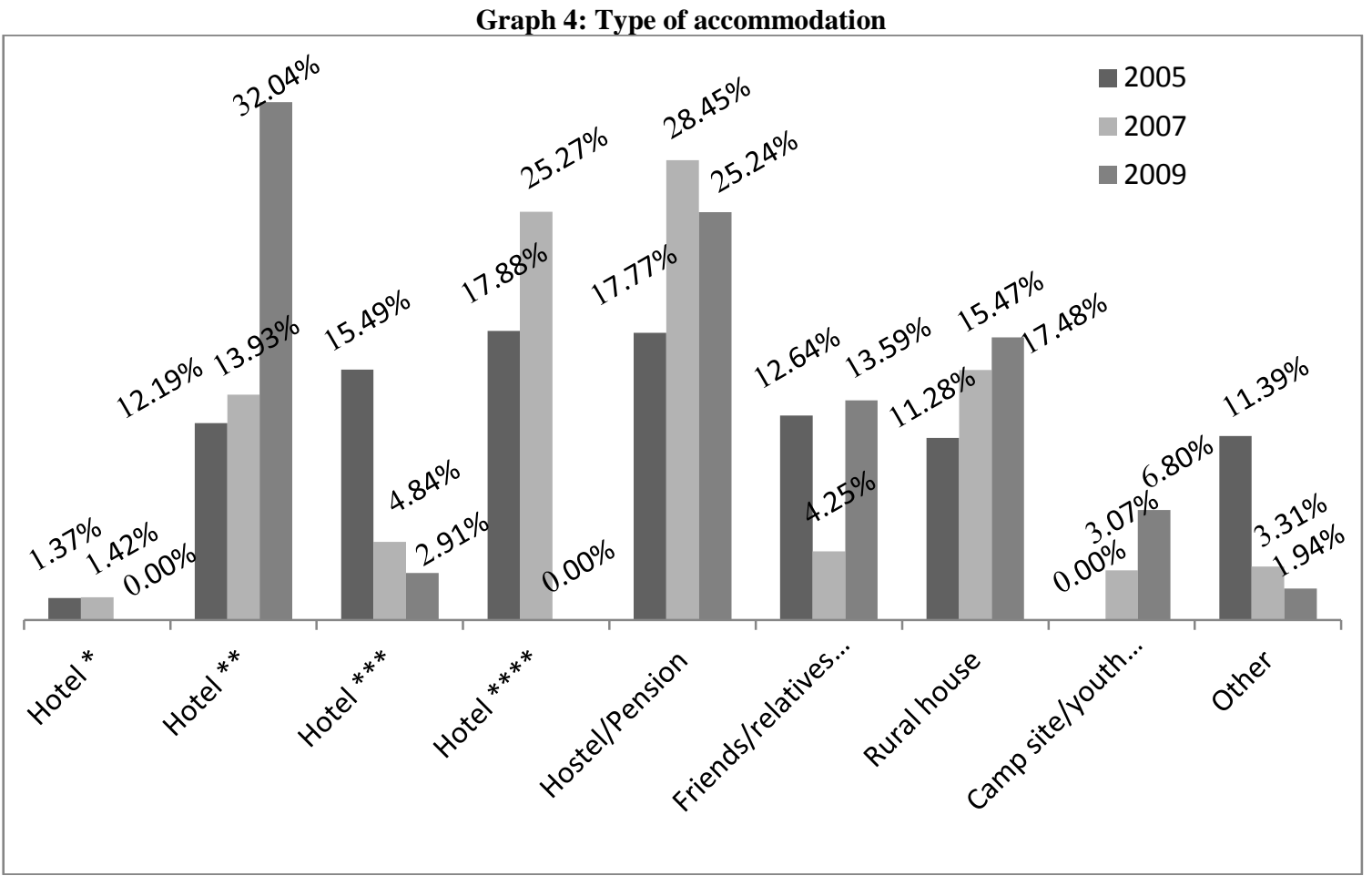

\section{$>\quad$ Nationality}

With regard to the nationality of visitors (Graph 5), a descent in the proportion of visitors from Spain is seen, and a rise in the number of visitors from abroad.

With regard to visitors from abroad, in 2005, the main country of origin was France, followed by the United Kingdom, Italy, USA and Germany; in 2007, this was the United Kingdom, USA, Germany and France; and in 2009, the United Kingdom, France, Germany, USA and Portugal. So there has not been much change in terms of the country of origin of foreign visitors.

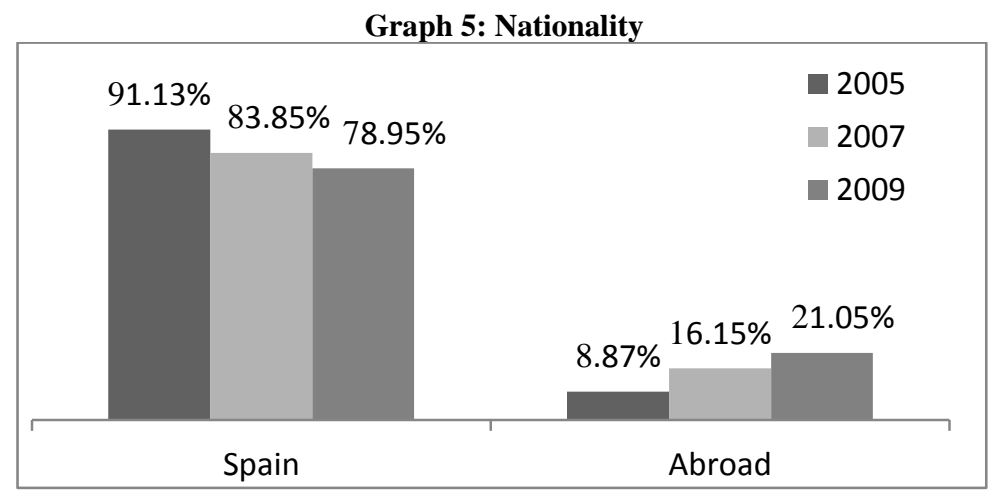




\section{CONCLUSIONS}

From the descriptive point of view, the main conclusions we can extract from this study are the characteristics of visitors and how they have changed over a five-year period, 2005 to 2009, allowing the behavior of the tourist consumers received by the city to be seen.

These results should allow tourism managers to adapt their supply to the needs demanded by society, and facilitate or enable the design of adequate marketing strategies for the situation of the tourist sector, so improving the city's competitive situation as a tourist destination and its image.

The strategy arising from these conclusions is one of orientation towards marketing or orientation towards the customer, in which strategic decision making depends on the desires and needs of real and potential customers, because the satisfaction of consumers can only be achieved by knowing them.

Longitudinal development gives us a dynamic focus, allowing us to see the adaptation of supply to demand and enable the detection of any deviations, facilitating their correction. The main conclusion to be pointed out from this longitudinal analysis is the positive evolution of the evaluation of the city of Cuenca compared with cities of similar characteristics, allowing it to consolidate itself as an inland tourist destination, with the ability to attract new visitors but also to gain their loyalty.

The expectations formulated theoretically about tourist consumers' evolution have been met, and the question arising is whether tourist sector businesses have adapted to these changes. If they have not, the products they are offering are out of date in relation to market trends, and the solution must be to adapt them to make up for lost ground and allow survival.

This process of adaptation to new demand has become more difficult with the present economic situation, in which visitors are not staying at home or renouncing their wishes to travel, enjoy themselves and escape from their day-to-day routine, but are taking care and watching over their budget when they come to travel, causing changes to their purchasing behavior and patterns, in the sense that they are reducing the lengths of their stays and seeking less sophisticated or refined services, where standard quality rules.

Tourism businesses need to adapt to this difficult, uncertain economic situation for the tourism business to suffer as little as possible. For this purpose, they need to make an effort in research, development and innovation to allow management to be made as technical as possible, enabling productivity increases and cost reductions among other short-term solutions such as promotions to increase the destination's appeal and allow a certain amount of light at the end of the tunnel to be seen, though at the moment it seems very dim. However, these steps need to be taken without causing a drop in quality, because that is what ensures competitiveness in the long term.

This study has a limitation which is the use of data from 2009: it is a work in progress which is part of a broader research project, and a future line of research proposed is to complete the longitudinal study with information from 2006, 2008, 2010 and 2011 providing more information about changes in the sector and allowing more relevant conclusions to be drawn and analysis of the most up-to-date situation possible to be made.

\section{AUTHOR INFORMATION}

María Cordente-Rodríguez, Ph.D. and Degree in Business Administration by University of Castilla-La Mancha. Lecturer in Marketing at Business Department. School of Business \& Economics. University CEU San Pablo (Spain). Research Interest: Tourism marketing, consumer behavior and e-learning. E-mail: maria.cordenterodriguez@ceu.es (Corresponding author)

Juan-Antonio Mondéjar-Jiménez, Ph.D. and Degree in Business Administration by University of Castilla-La Mancha. Degree in Advanced Studies in Marketing at the same university. Associate Professor in Marketing at Business Administration Department. Faculty of Social Sciences of Cuenca. University of Castilla-La Mancha (Spain). Research Interest: Consumer behavior, price perception, e-learning and tourism marketing. E-mail: $\underline{\text { JuanAntonio.Mondejar@uclm.es }}$ 
Águeda Esteban-Talaya, Ph.D. and Degree in Business Administration by University Complutense of Madrid. Professor in Marketing at Business Administration Department. Faculty of Law and Social Sciences of Toledo. University of Castilla-La Mancha (Spain). Research Interest: Tourism marketing, tourist consumer's behavior and bank marketing. E-mail: Agueda.Esteban@uclm.es

\section{REFERENCES}

1. Crompton, J.L. (1979): “Motivations for Pleasure Vacations", Annals of Tourism Research, vol. 6, nº 4, pp. 408-242.

2. Dann, G.M.S. (1977): "Anomie, ego-enhancement and tourism", Annals of Tourism Research, $\mathrm{n}^{\circ}$ 4, pp. 184-194.

3. De Borja, L; Casanovas, J.A. \& Bosch, R. (2002): El consumidor turístico, Esic, Madrid.

4. Devesa, M. \& Palacios, A. (2005): "Predicciones en el nivel de satisfacción percibida por los turistas a partir de variables motivacionales y de valoración de la visita", Tribuna de Economía, ICE, March-April, pp. 241-255.

5. $\quad$ Esteban, A. (1996): "El Marketing Turístico: LA Orientación de la Actividad hacia el Consumidor”. In Pedreño, A. \& Monfort, V.M. (eds.): Introducción a la Economía del Turismo en España, Civitas, Madrid, pp. 247-273.

6. $\quad$ Esteban, A. (2005): "La demanda de servicios culturales: aspectos motivacionales y funcionales del consumidor de turismo cultural”. In Gómez, M.A.; Mondéjar, J.A. \& Sevilla, C. (coords.): Retos y oportunidades en la gestión del turismo cultural y de ciudad. Ediciones de la Universidad de Castilla-La Mancha, pp. 95-114, Cuenca.

7. Gaztelumendi, I. (2009); "Nuevas tendencias del turismo en ciudades patrimonio de la humanidad: el proyecto Compostur". In Mondéjar, J.A. \& Gómez, M.A. (coords.): Turismo cultural en ciudades Patrimonio de la Humanidad. Ediciones de la Universidad de Castilla-La Mancha, pp. 53-62, Cuenca.

8. Gómez, M.A.; Mondéjar, J.A. \& Sevilla, C. (2005): Gestión del turismo cultural y de ciudad, Ediciones de la Universidad de Castilla-La Mancha, Cuenca.

9. Herrero, L.C. (2000): "El patrimonio histórico o la riqueza de las regiones", in Turismo cultural: el patrimonio histórico como fuente de riqueza, pp. 11-21, Valladolid.

10. Mayo, E.J. \& Jarvis, L.P. (1981): The Psychology of Leisure Travel, CBI Publishing, Boston.

11. Mazanec, J.A. (1983): “Tourist Behavior Model Building: A Causal Approach”, The Tourist Review, nº 1, pp. 9-19

12. Mediano, L. (2002): "Incidencia del nuevo consumidor turístico en la estrategia de marketing", Revista de Dirección y Administración de Empresas, $\mathrm{n}^{\circ}$ 10, pp. 99-117.

13. Mill, A.S. \& Morrison, A.M. (1992): The Tourism System: An Introductory Text, Prentice Hall, Englewood Cliffs, New Jersey.

14. Molera, L. \& Albaladejo, I.P. (2007): "Profiling segments of tourists in rural areas of south-eastern Spain", Tourism Management, $\mathrm{n}^{\circ}$ 28, pp. 757-767.

15. Molina, A. (2002): "Análisis de imagen y utilidad generada por los folletos de información turística: Evaluación e influencia sobre la elección de un destino turístico". Thesis Doctoral. University of CastillaLa Mancha.

16. Mondéjar, J.A.; Mondéjar, J. \& Sevilla, C. (2009); “Experiencias de gestión en Cuenca como ciudad patrimonio". In Mondéjar, J.A. \& Gómez, M.A. (coords.): Turismo cultural en ciudades Patrimonio de la Humanidad. Ediciones de la Universidad de Castilla-La Mancha, pp. 85-106, Cuenca.

17. Plog, S.C. (1974): "Why Destination Areas Rise and Fall in Popularity", The Cornell Hotel and Restaurant Quarterly, vol. 4, no 4, pp. 55-58. 


\section{NOTES}

